SUSTAINABLE FORESTRY

COLLECTION 81-82, 2020
ODRŽIVO ŠUMARSTVO

ZBORNIK RADOVA 81-82, 2020

UDK 628.35(497.11)=111

Original scientific paper

\title{
GUIDELINES FOR THE INTRODUCTION OF BIOLOGICAL SYSTEMS FOR REVITALIZATION OF POLLUTED WATER AND WASTEWATER TREATMENT IN STRATEGIC DOCUMENTS IN SERBIA
}

\author{
Ljiljana BRA ̌́ANAC-BOSANAC ${ }^{l}$, Nevena $\check{C} U L E^{l}$, \\ Aleksandar LUČIĆ ${ }^{l}$, Milorad VESELINOVIĆ , Suzana MITROVIĆ $^{1}$
}

\begin{abstract}
Long-term courses of water protection and management are based on the fact that Serbia belongs to the region of UNECE countries (UN Economic Commission for Europe) while most of its territory belongs to the Danube River Basin where countries have established multilateral coordination and cooperation in water management. Since the Republic of Serbia is currently in the process of joining the EU, it is obliged to gradually align its strategic decisions in the field of water to the documents that apply to EU member states. The degree of the state's readiness to join the EU will be assessed based on the adequate introduction of internationally accepted principles of water management into the strategic documents and their establishment and implementation at the state level and within international cooperation in this area. Serbia will not be granted EU membership unless it invests significant funds in wastewater and polluted water treatment, as this is one of the priorities in meeting the criteria to open Chapter 27. The introduction of biological systems into the standard water treatment infrastructure provides higher levels of environmental protection and contributes to the integration of environmental requirements, opinions and principles into the plans and programs that encourage and promote sustainable development. The paper will present the current level of alignment between EU and Serbian water-related legislation and propose specific guidelines for the introduction of biological systems for the treatment of polluted water in strategic documents in Serbia.
\end{abstract}

Keywords: revitalization of polluted water, wastewater treatment, EU strategic documents, biological water-treatment systems, guidelines, Serbia.

\footnotetext{
${ }^{1}$ Institute of Forestry, 3 Kneza Viseslava, Belgrade, Serbia

Corresponding author: Ljiljana Brašanac-Bosanac, e-mail: brasanlj@yahoo.com
} 


\section{SMERNICE ZA UVOĐENJE BIOLOŠKIH SISTEMA ZA REVITALIZACIJU ZAGAĐENIH I PREČIŠĆAVANJE OTPADNIH VODA U STRATEŠKA DOKUMENTA U SRBIJI}

Izvod: Dugoročni pravci zaštite i upravljanja vodama zasnovani su na činjenici da Srbija pripada regionu zemalja UNECE (Ekonomska komisija UN za Evropu) i najvećim delom teritorije slivu Dunava na kome su države uspostavile multilateralnu koordinaciju $i$ saradnju u upravljanju vodama. Pošto se Republika Srbija trenutno nalazi u procesu pridruživanja EU, sledi $i$ obaveza da svoje strateške odluke u oblasti voda postepeno prilagođava dokumentima koji važe za države članice EU. Od adekvatnog uvođenja međunarodno prihvaćenih principa upravljanja vodama u strateška dokumenta $i$ uspostavljanja i njihovog sprovođenja na državnom nivou i u okviru međunarodne saradnje u ovoj oblasti, zavisiće $i$ opšta ocena stepena spremnosti države za priključenje EU. Srbija neće moći da pristupi Evropskoj uniji ukoliko ne uloži značajna sredstva u prečišćavanje otpadnih $i$ zagađenih voda, jer je to jedan od prioriteta u ispunjavanju kriterijuma za poglavlje 27. Uvođenje bioloških sistema u standardu infrastrukturu za prečišćavanje zagađenih voda u direktnoj je vezi sa obezbeđivanjem višeg nivoa zaštite životne sredine $i$ integracije ekoloških zahteva, mišljenja i načela u planove i programe u cilju podsticanja $i$ unapređenja održivog razvoja. U radu će se prikazati dosadašnji stepen usaglašenosti vodnog zakonodavstva EU i Srbije i predložiti konkretne smernice za uvođenje bioloških sistema za prečišćavanje zagađenih voda u strateška dokumenta u Srbiji.

Ključne reči: revitalizacija zagađenih voda, prečišćavanje otpadnih voda, strateška dokumenta EU, biološki sistemi za prečišćavanje voda, smernice, Srbija.

\section{INTRODUCTION}

Biological systems as a type of green technology enable the removal of different categories of pollutants from polluted water and wastewater with great efficiency. It is done in a completely natural way, without the use of chemicals or additional energy, and thanks to symbiotic relationships between its main components (plants, microorganisms, algae, substrate, and water) (Čule et al., 2017).

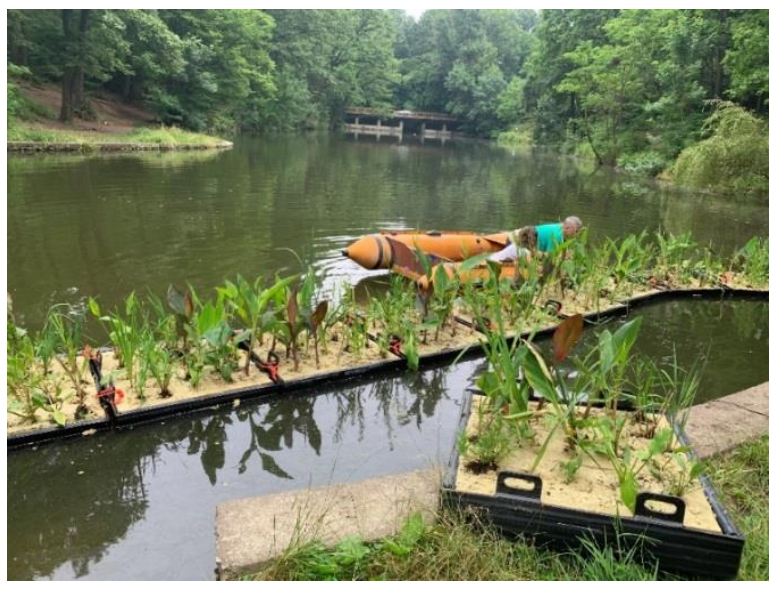

Figure 1. A biological system, 2020 (Orig.) 
Despite their innovativeness, biological systems have not been recognized in the laws related to environmental protection, nature protection, water management and other relevant regulations of the Republic of Serbia yet. However, it is encouraging that the current legislation makes provision for the introduction of various biological water treatment systems in Serbia, either as an independent process in some areas or as a supplement to conventional treatment systems.

In the sector of environmental protection, i.e., in the field of water protection, the basic requirements set by the European Union to its potential members are: improvement and expansion of the water supply network; improvement and expansion of the sewerage network; construction of wastewater treatment facilities; cleaning of contaminated soil and polluted watercourses with unsatisfactory water quality; protection of (aquatic) ecosystems, habitats and protected species from economic and environmental pressures; prevention of further pollution of both surface water and groundwater, etc. (Stevanović-Čarapina, 2005).

EU candidate countries, including Serbia, need to harmonize their regulations with those of EU legislation related to water, which includes various and numerous directives, regulations, decisions, and resolutions. The group of water-related EU regulations includes regulations related to integrated pollution prevention and control (IPPC), regulations governing the field of environmental impact assessment (EIA), strategic environmental assessment (SEA), regulations governing the public access to environmental information, public participation in decision-making on environmental issues, waste management, as well as numerous regulations governing the protection of other aspects of the environment (soil, air, biodiversity) and others.

Having recognized the aspirations of an environmentally conscious society to acknowledge water management and protection as one of its main tasks, the Secretariat for Environmental Protection of the City of Belgrade and the Institute of Forestry, Belgrade set up the project "Revitalization of the Topčiderska River using biological systems for the treatment of polluted waters" in 2014, and then in 2016 the project "Revitalization of the lake at the locality of Trešnja by the system of Floating Islands".

In both projects, special attention was paid to the harmonization of EU and Serbian water legislation and the proposal of measures that need to be implemented in order to integrate biological systems into the standard infrastructure for the revitalization of polluted water and treatment of wastewater and introduce them into the strategic documents in Serbia. This paper gives a brief overview of the results that have been achieved in this field.

\section{METHODOLOGY}

The study was performed using the method of analysis with elements of generalization and inductive-deductive approaches. The method of generalization "... forms general attitudes on the basis of individual ones" (Miljević, 2007). The method of induction "... derives general attitudes from several special ones" (Milosavljević, Radosavljević, 2008), while the method of deduction, which "... 
represents a form of inference", acquires special knowledge on the basis of "... general legal understanding" (Miljević, 2007). Of the basic scientific methods, a comparative method was used, the subject of which is "... identity, similarity and diversity of the same phenomenon at different times and in different spaces determined by adequate measures, identical or diverse phenomena in a defined space and time" (Miljević, 2007). To study the content of documents, content analysis was applied as a kind of partial analysis (Milosavljević, Radosavljević, 2008).

The data on EU and Serbian Water Law was analyzed by comparing different international declarations, legal regulations and acts in the European Union and Serbia in the field of water and environmental protection. The data on biological systems for the treatment of polluted water and wastewater was analyzed on the basis of collected literature data and previous knowledge of researchers engaged in both projects.

\section{RESULTS AND DISCUSSION}

The European Union does not compel any country on how to organize its legislation. The approximation of law is a joint obligation to be fulfilled to gain membership in the European Union. It means that countries aspiring to join the European Union must align their national laws, rules, and procedures to enable efficient transposition of the overall legal structure of the EU (Brašanac-Bosanac, Lj., 2014). As the obligation to approximate continues after accession, the preaccession approximation process becomes an opportunity for a country to organize its institutions and procedures and to train its staff for daily tasks and responsibilities of European Union law-making, implementation, and enforcement.

Within the group of EU regulations related to the environment, there are many regulations applicable to issues of water protection and water management. According to Todić, D. and Isoski, Z. (2005), these include, before anything else, all those regulations that refer to integrated pollution prevention and control (IPPC). Then, there are the regulations that relate to the field of environmental impact assessment (EIA), strategic environmental assessment (SEA), or the public access to environmental information. They also include numerous regulations governing the protection of other aspects of the environment (soil, air, biodiversity), waste management, and others.

The field of water protection and water management is regulated by 17 directives. The WFD is an "umbrella" directive that includes and links other important directives that directly or indirectly relate to the field of water. European Union water legislation is of paramount importance not only for the Member States but also for all countries that intend to cooperate or become members of the Union. The most important act in the field of water is the Water Framework Directive (WFD). It is an operational tool to achieve the key goal of European water policy, which is "comprehensive protection of all water bodies, taking into account the natural interaction between them in quantitative and qualitative terms, with the application of the principle of integrated water resources management ". The concept of integration of all relevant segments (water resources at the basin level, environmental protection, water use, legislation, decision-making levels, water 
management of transboundary basins through international cooperation, etc.) is the only key to achieving the set goals. With the adoption of the Water Framework Directive, water resources in the EU have become a concern of the whole Union, which implies the obligation of each Member State to harmonize the legislative, and technical and economic approach to water management and ensure a coherent water management strategy. Countries that are on their way to becoming EU members also have this obligation.

\section{Introduction of biological systems into the standard infrastructure for the revitalization of polluted water and treatment of wastewater}

$\checkmark \quad$ In order to introduce a biological system for the revitalization of polluted water and treatment of wastewater into the standard infrastructure, which is prescribed by appropriate legislation, certain by-laws, and standard planning documentation, it is necessary to conduct preliminary, comprehensive research at a particular location and polluted watercourse or water surface.

$\checkmark$ If the results of research at a particular location indicate that the applied biological treatment can reduce the content of different categories of pollutants that are parameters for assessing the ecological status of water, the data can be used as a direct indicator of the efficiency of biological systems for the revitalization of polluted water and treatment of wastewater and allow their introduction into appropriate strategies, programs, and plans.

$\checkmark$ It is necessary to determine the limiting concentrations of pollutants and percentages of pollution reduction after biological wastewater treatment.

$\checkmark$ Bearing in mind that there are significant differences between rural and urban areas regarding the indicators of development such as demographic characteristics (population and population density), type of economic activity (dominant industrial or agricultural activity), income (higher or lower revenues), existing communal infrastructure (developed or poorly developed water supply and sewerage network, the presence of septic tanks), it is necessary to adjust the relevant by-laws to these conditions.

$\checkmark$ The concept of the rural system for wastewater collection and treatment needs to be adapted to the specific area and the primary goal is to protect water from pollution (especially drinking water sources of local water supply systems) and thus protect human and livestock health.

$\checkmark$ In order to improve the condition of the communal infrastructure in rural areas, when planning and building biological systems for wastewater collection and treatment, it is necessary to prescribe precise and concrete rules of conduct for individuals, legal entities, and competent local self-government bodies. The technical conditions of the by-law would refer to the design, construction, construction supervision, use, and maintenance of facilities and devices for wastewater collection and treatment in rural areas where technical, economic, and organizational requirements for a public sewerage system cannot be met. The conditions would refer to natural and legal persons who, as owners or users, build or already have residential, sports, educational, or tourism facilities. 
$\checkmark$ Local self-government bodies are obliged to develop an implementation program and submit its draft to the Ministry in charge of water management and environment to assess its content.

$\checkmark$ Besides the by-law that serves as a planning act in the field of planning and construction, it is necessary to adopt special by-laws related to environmental protection.

$\checkmark$ In dispersed rural settlements, there is a possibility that users are not willing to accept the new concept, which calls for a previous education campaign. Before the implementation, a pilot system must be developed and by-laws made in different environments.

$\checkmark$ Regardless of the type of water supply and the size of the biological system, when introducing biological systems into the standard infrastructure for the treatment of polluted water, all principles of risk management in regular and emergency situations must be applied, so that measures for the remediation of the state resulting from extreme events are of smaller extent but more effective.

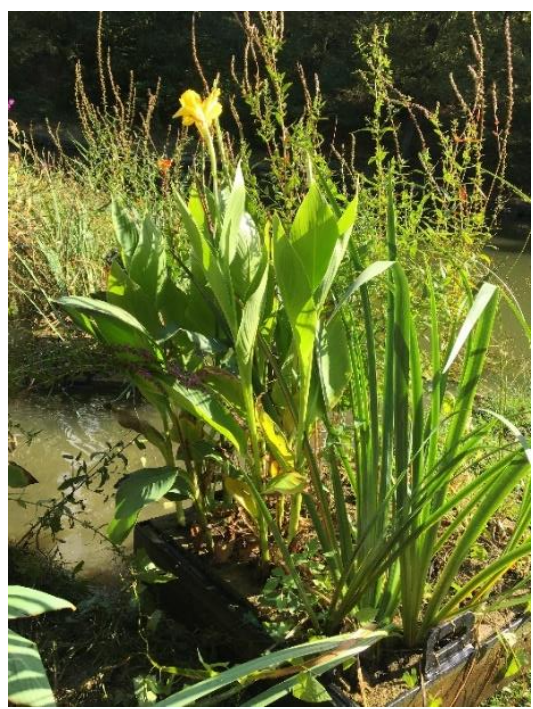

Figure 2. A floating island after the first year of revitalization, 2019 (Orig.)

\section{CONCLUSIONS}

The harmonization of EU and Serbian water legislation is a long-term process, which implies the joint engagement of all relevant actors, both the state and the business, academic, and scientific community and international organizations. It is extremely important that the Republic of Serbia is actively involved in EU development programs, because it takes many years for the prescribed and foreseen innovations and guidelines to be applied in practice. In recent years, the Republic of Serbia has largely harmonized its water legislation with the EU Water Framework Directive and accompanying regulations (2010a, $2010 \mathrm{~b}, 2011,2015)$. In order to adequately and timely react and establish more successful cooperation with the countries of the European Union in the coming period, it will be necessary: 
$\checkmark$ to continue the process of integration, multilateral and bilateral cooperation following the recommendations of the European Directive in the field of EU water policy WFD/2000/60, Directive 2007/60 EC on flood risk assessment and management and other EU directives in the field of water $(1998,2000$, 2009) .

$\checkmark$ to conduct water quality monitoring and prevent and sanction hazardous situations and negligence of individuals;

$\checkmark$ to conceptualize an adequate state response to the consequences;

$\checkmark$ to promote biological systems for the revitalization of polluted and treatment of wastewater and introduce them into standard infrastructure through national strategic documents and action plans wherever previous research shows that it will be possible and efficient.

In order to preserve and improve water resources in the Republic of Serbia, it is necessary to establish such social relations in which the use and protection of the quality of water and environment in riparian areas becomes a concern of each and every individual. Such a goal requires education and participation of the scientific and professional public and incentives based on economic relations and public awareness.

The introduction of biological systems in the standard infrastructure for the revitalization of polluted water and treatment of wastewater is an important instrument of the general, strategic, and previously harmonized environmental and development interests of Serbia. Their implementation is directly related to ensuring a higher level of environmental protection and the integration of environmental requirements, opinions, and principles into plans and programs to encourage and promote sustainable development.

Note: The paper is the result of research within the projects: "Revitalization of Topčiderska River using biological systems for the treatment of polluted water" (Contract No. V-01 401.1-83) and "Revitalization of the lake at the locality of Trešnja by the System of Floating Islands" (Contract No. V-01 401.1-50), funded by the Secretariat for Environmental Protection of the City of Belgrade.

\section{REFERENCES}

Brašanac-Bosanac, Lj. (2014): The climate change - strategies and legislation in Serbia, Sustainable Forestry, Vol. 69-70, Institute of Forestry, pp. 7-15, Belgrade. ISSN 18211046.

Bulmer M. (1977): Sociological research methods, An introduction, second edition, Transaction Publishers, New Brunswick and London, p. 354

Čule, N., Lučić, A., Dražić, D., Popović, V., Veselinović, M., Brašanac-Bosanac, Lj., Mitrović, S. (2017): Construction of floating treatment wetlands for the remediation of polluted waters, Sustainable Forestry, Vol. 75-76, Institute of Forestry, p. 1-12, Belgrade. ISSN 1821-1046. 
Group of authors (2016): Revitalization of the Topčiderska River using biological systems for the treatment of polluted waters. Institute of Forestry, Belgrade, the City of Belgrade Administration - Secretariat for Environmental Protection, 159. Available at:

http://www.beograd.rs/images/data/98e470b6829e9ce1a59ff91b9a926ad2_1251546056.pdf

Milosavljević S., Radosavljević I. (2008): Fundamentals of Methodology of Political Sciences, Official Gazette, Belgrade, p. 694.

Miljević M. (2007): Methodology of scientific work - script, University of East Sarajevo Faculty of Philosophy, Sarajevo, p. 328.

Neuman W.L. (2014): Qualitative and Quantitative Approaches, 7th edition, Pearson Inc., Harlow, p. 599.

Todić, D., Isoski, Z. (2005): National specifics and water law of the EU and Serbia. Proceedings: Symposium with International Participation "Environment towards Europe", Belgrade, 5-8. June, pp. 237-243 (CD-ROM).

Council Directive 91/271/EEC of 21 May 1991.

Regulation on limit values of pollutants in surface waters, groundwaters and sediment and deadlines for their achievement (Official Gazette of RS, 50/12)

Zdragas, A., Zalidis, G.C., Takavakoglou, V., Katsavouni, S., Anastasiadis, E.T., Eskridge, K. (2003): The effects of environmental conditions on the ability of a constructed wetland to disinfect municipal wastewaters. Environmental Management, 29 (4), p. 510-515.

(1998): Council Directive 98/83/EC of 3 November 1998 on the quality of water intended for human consumption, Official Journal L 330 , 05/12/1998 p. 0032-0054.

(2000): European Commission Directive 2000/60/EC of the European Parliament and of the Council of 23 October 2000 establishing a framework for Community action in the field of water policy, Official Journal L 327, 22/12/2000, p. 0001-0073.

(2009): Directive 2009/90/EC of the European Parliament and of the Council of 25 November 2009 on the taking-up and pursuit of the business of Insurance and Reinsurance (Solvency II) (Text with EEA relevance), Special edition in Croatian: Chapter 06 Volume 010 p.153-307; http://data.europa.eu/eli/dir/2009/138/oj

(2010a): Law on Waters (Official Gazette of RS, No. 30/10 and 93/12).

(2010b): Decision on Determining the List of Waters of the First Order (Official Gazette of the RS, No. 83/10).

(2011): Regulation on the parameters of ecological and chemical status of surface waters and parameters of chemical status and quantitative status of groundwaters (Official Gazette of the RS 74/2011).

(2011): Regulation on limit values of priority and priority hazardous substances that pollute surface waters and deadlines for their achievement (Official Gazette of RS, No. 35/11). 
(2015): Water Management Strategy on the territory of the Republic of Serbia - Analysis and Research, Government of the Republic of Serbia, Ministry of Agriculture and Environmental Protection, Jaroslav Černi Water Institute, Belgrade, p.1-241.

\title{
GUIDELINES FOR THE INTRODUCTION OF BIOLOGICAL SYSTEMS FOR REVITALIZATION OF POLLUTED WATER AND WASTEWATER TREATMENT IN STRATEGIC DOCUMENTS IN SERBIA
}

\author{
Ljiljana BRA $\check{S} A N A C$-BOSANAC, Nevena $\check{C} U L E$, \\ Aleksandar LUČIĆ, Milorad VESELINOVIĆ, Suzana MITROVIĆ
}

\section{Summary}

Despite their innovativeness, biological systems for revitalization of polluted water and wastewater treatment, have not been recognized in the laws related to environmental protection, nature protection, water management and other relevant regulations of the Republic of Serbia yet. EU candidate countries, including Serbia, need to harmonize their regulations with those of EU legislation related to water, which includes various and numerous directives, regulations, decisions, and resolutions. In order to introduce a biological system for the revitalization of polluted water and treatment of wastewater into the standard infrastructure, which is prescribed by appropriate legislation, certain by-laws, and standard planning documentation, it is necessary to conduct preliminary, comprehensive research at a particular location and polluted watercourse or water surface. The introduction of biological systems in the standard infrastructure for the revitalization of polluted water and treatment of wastewater is an important instrument of the general, strategic, and previously harmonized environmental and development interests of Serbia.

\section{SMERNICE ZA UVOĐENJE BIOLOŠKIH SISTEMA ZA REVITALIZACIJU ZAGAĐENIH I PREČIŠĆAVANJE OTPADNIH VODA U STRATEŠKA DOKUMENTA U SRBIJI}

\author{
Ljiljana BRAŠANAC-BOSANAC, Nevena ČULE, \\ Aleksandar LUČIĆ, Milorad VESELINOVIĆ, Suzana MITROVIĆ
}

\section{Rezime}

Iako predstavljaju inovativnu tehnologiju, biološki sistemi za revitalizaciju zagađenih i prečišćavanje otpadnih voda još uvek nisu prepoznati u zakonima koji regulišu oblasti zaštite životne sredine, zaštite prirode, vode i drugim relevantnim propisima Republike Srbije. Zemlje kandidati za ulazak u EU, uključujući i Srbiju moraju da usklade svoje propise sa onim što obuhvata legislativa EU u oblasti vodnog prava u koju spadaju različite i brojne direktive, uredbe, odluke i rezolucije. Da bi se biološki sistem za revitalizaciju zagađenih i prečišćavanje otpadnih voda uveo u standardnu infrastrukturu, koju propisuje odgovarajuća zakonska regulativa, pojedini podzakonski akti i standardna planska dokumentacija, neophodno je sprovesti preliminarna, sveobuhvatna istraživanja na određenoj lokaciji i zagađenom vodotoku ili vodenoj površini. Uvođenje bioloških sistema u standardu infrastrukturu za revitalizaciju zagađenih i prečišćavanje otpadnih voda predstavlja značajan instrument generalnih, strateških i prethodnog usaglašenih ekoloških i razvojnih interesa Srbije. 